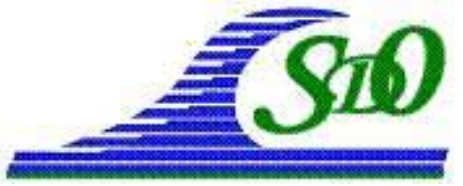

XI ${ }^{\text {èmes }}$ Journées Nationales Génie Côtier - Génie Civil

Les Sables d'Olonne, 22-25 juin 2010

DOI:10.5150/jngcgc.2010.075-T @ Editions Paralia CFL

disponible en ligne - http://www.paralia.fr - available online

\title{
Restoration program of bay ecosystem through eco-compatible management of river basin complex around the bay
}

\author{
Tetsuro TSUJIMOTO ${ }^{1}$ \\ 1. Nagoya University, Furo-cho, Chikusa-ku, Nagoya, 464-8603, Japan. \\ ttsujimoto@genv.nagoya-u.ac.jp
}

\begin{abstract}
:
In Japan, three metropolises are located downstream of several rivers and facing bays. A river basin is a unit of hydrological cycle and not only water but also various materials are conveyed to form flux networks. Various characteristic landscapes are distributed in a river basin, and they change the passing fluxes and create various ecosystem services for people. Previously, we received various resources as ecosystem services. Because of rapid increase of population and economic growth, we have added artificial flux networks and constructed artificial facilities to get services to compensate or replace the ecosystem service. Serious environmental load from metropolis and other areas in a river basin which support human activities have caused degradation of both water quality and ecosystem in river basins and bay area. Restoration of bay area facing a the metropolis is one of the highest concerns is closely related to the restoration of a river basin. In order to realize such restoration, we are working to establish the framework of ecosystem assessment by which we are able to suggest combination of policies and programs to restore our environment with higher reliability for sustainability. The assessment frame work is composed of (1) flux network model, (2) ecosystem modeling for each categorized landscape and (3) standardizing and integrated evaluation of ecosystem service. These three tool boxes should be functionally combined with one another for assessment from the view point of eco-compatible river basin which may bring sustainability. This paper describes the content of our research project, methodologies, tentative results and perspective.
\end{abstract}

\section{Keywords:}

Sustainability - Eco-compatible river basin management - Ecosystem service - River basin complex - Bay environment and ecosystem - Flux network - Ecosystem restoration

\section{Mots-clés :}

Développement durable - Gestion eco-compatible de bassin versant - Bassin versant complexe - Ecosystème de baie - Réseau d'écoulement - Restauration d'écosystèmes 


\section{Introduction}

In Japan, three metropolises (Tokyo, Osaka and Nagoya) are located downstream of several rivers and facing bays respectively. A river basin is a unit of hydrological cycle and not only water but also various materials including bio-elements are conveyed to form flux networks. Inside a river basin, various characteristic landscapes which form an ecosystem are distributed, where fluxes are changed and bring various ecosystem services to the people living there. Previously, we received various resources from surrounding river basins as ecosystem service. Because of rapid increase of population and economic growth, we have added artificial flux networks such as irrigation, water supply and sewage system and we have got additional service and/or functions from such artificial facilities. By addition of artificial network, multiple river basins are connected from the view of water and material cycles, and the system must be called "river basin complex". Additions of artificial facilities and networks of fluxes have altered our environment and we have lost sound ecosystem and biodiversity in river basins and bay area. Furthermore, additional facilities and network system have consumed much fossil fuel and discharged much GHG (green house gas) which threaten our sustainability. Serious environmental load from metropolis and other areas in river basins which support human activity have caused degradation of water quality and ecosystem even in bay areas. Restoration of bay area facing a metropolis is the highest concern of metropolitan area and fishery, and it is related to the restoration of river basins. The environment and ecosystem in a bay is a mirror of those of river basin complexes.

Figure 1 is a satellite photograph of the river basin complex around the Ise bay, which is composed of river basins of 10 major rivers, and Nagoya, a metropolis with population of 2.2 million, located at the downstream of the rivers facing the Ise bay. Nagoya is supported by these river basins from various view points: Flood protection, water resources, energy, food supply from agriculture and fishery, and many kinds of industrial products. Prosperity of the metropolis Nagoya is supported by the river basin complex and its reclamation. The metropolis has been able to accumulate wealth, convenience, comfort, and also knowledge and technology, and its diffusion has brought its expansion. However, it has brought various environmental degradations: Not only pollution problems but also ecosystem degradation, global warming and resources exhaustion, and we recognize they threaten our sustainability. First of all, the metropolitan area had been aware that the bay environments should be recovered. Awareness has evolved from pollution control to ecosystem soundness and then to our sustainability. The environment of bay is closely related to the river basins from mountains to sea. Various policy menus and tackling solutions by citizens have been proposed and started. However, those activities are independent from one another, and they often even cancel out. In order to combine various activities efficiently and promote them, it is necessary to establish the ecosystem assessment techniques for eco- 
compatible river basin complex. So, we have organized the research project team from university and national institutes of government ministries serving national land management (ministry of land, infrastructure, transport and tourism, ministry of agriculture, forestry and fishery, and ministry of the environment), and we won the fund from the ministry of education, culture, sports, science and technology (TSUJIMOTO $e t$ al. 2008).

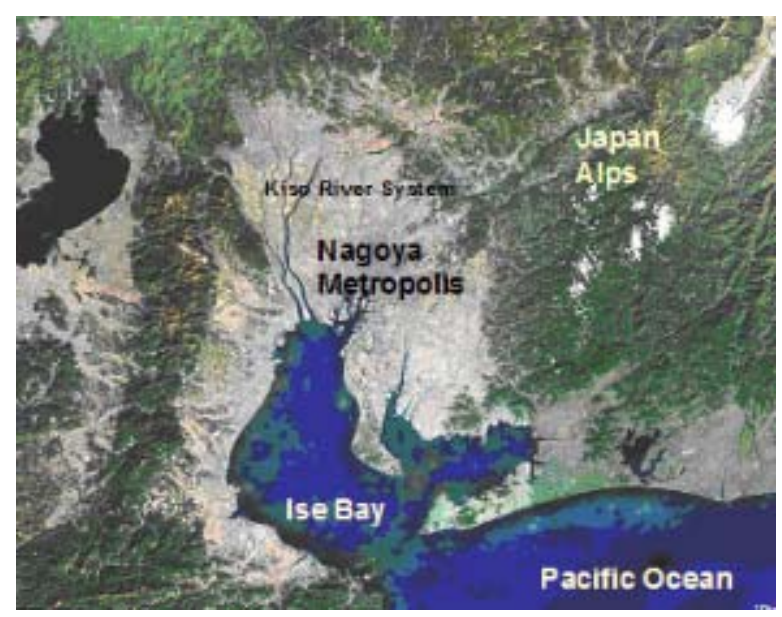

Figure 1. Satellite photograph of the Ise bay river basin complex.

\section{River basin complex around a bay}

A river basin is a hydrological unit where rainfall is gradually concentrated into a river system and various materials as well as sediment and bio-elements are transported with water. Sediment transport brings about various topographies and they form various local physical backgrounds of landscapes. Hence, various local landscapes are distributed and connected by flux network of water and materials in a river basin as shown in Fig. 2. In local landscapes, various physical back-grounds provide habitats and peculiar spaces where various geo-bio-chemical processes occur in bio-element cycle, and they support various organisms as ecosystem. Here the landscape no longer means merely a peculiar physical background but it can be identified with local ecosystem as an interrelating system (see Fig. 3). To sum up, flux networks govern the functions of local landscapes and reversely local landscapes change the fluxes locally to alter the flux network. This is a feedback system.

As already mentioned, rapid change due to increase of human population and urbanization have brought artificial connection of flux networks with construction of various facilities. River basin complex, as amalgamation of multiple river basins, has become a unit of land and environmental management where local landscapes and artificial facilities are connected by flux network of water and materials and they change the flux and bring services and/or functions to the people living there (see Fig. 4). 


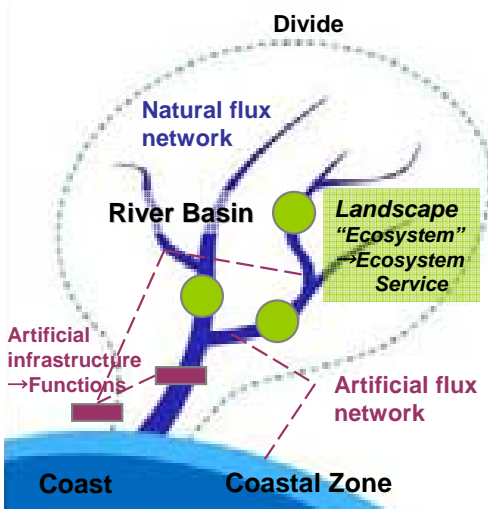

Figure 2. River basin as flux network assembly with distributed landscapes.

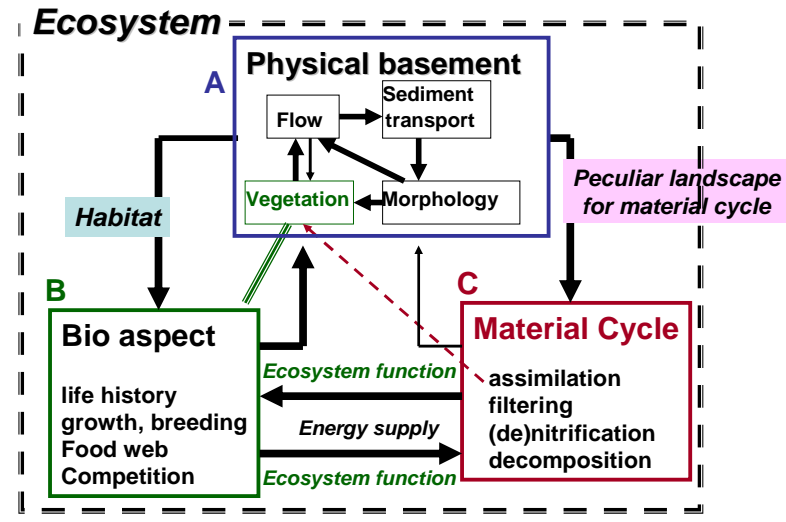

Figure 3. Ecosystem as interrelating system.

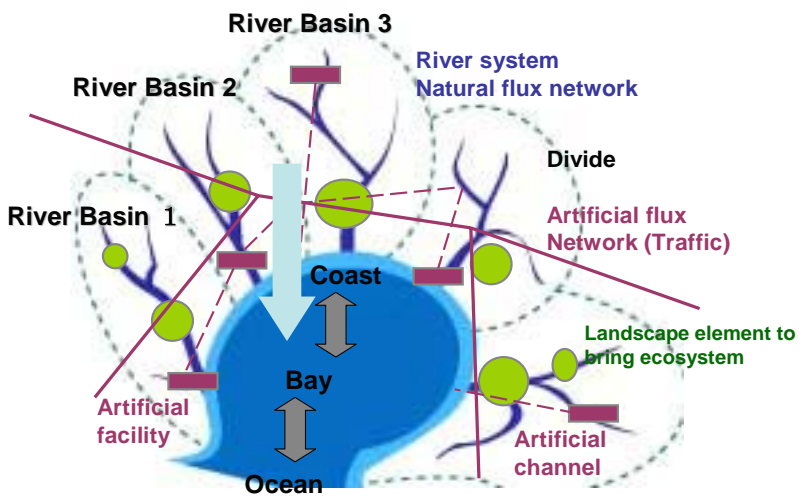

Figure 4. River basin complex as amalgamation of multiple river basins.

Furthermore, the rivers in a river basin complex discharge water and materials into the same water area, a bay, and the metropolis stretches facing the bay. For this reason, this amalgamation of multiple river basins has the same fate with the bay. Inside a bay, there is a peculiar dynamics of water and materials influenced by wind, tide, current in the ocean as well as inflows of water and materials from rivers, and such a hydrodynamics in a bay is a kind of flux behavior $\left(\phi_{L}\right)$ which conveys water and materials everywhere inside a bay. There are several landscapes with ecosystems related to human activities such as fishery and leisure in a bay, particularly along a coast line. Figure 5 shows that influxes from the river basin complex $\phi_{L}$ (and from the ocean $\left(\phi_{S}\right)$ ) are the boundary conditions for hydrodynamics inside a bay. The bay hydrodynamics represented by various fluxes $\phi_{B}$ are subject to the functions of various landscapes, the change in flux and ecosystem service, $(\Delta \phi$ and $E S)$ particularly along the coast line, and the change of flux $(\Delta \phi)$ brought by the roles of landscapes is fed back to the bay dynamics $\left(\phi_{B}\right)$. 


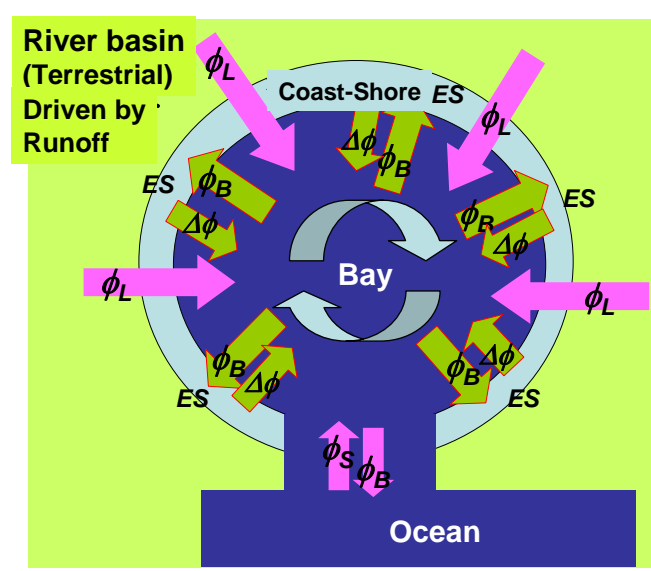

Figure 5. Flux behavior inside a bay and categorized landscapes along coast line.

\section{Models describing river basin complex and bay area}

Not only for river basin complex but also for the bay, we need two types of models: TB1 and TB2. TB1 (Tool Box 1) is to describe flux network of water and various materials, and TB2 (Tool Box 2) is to describe functions of various landscape: how to change the fluxes and how to bring ecosystem service. TB1 for river basin complex is based on the so-called runoff model but it is necessary to connect it to artificial networks and local changes in fluxes by individual landscapes given by TB2 (TSUJIMOTO et al., 2010). TB2 is a model to describe the mechanism of the ecosystem for each landscape and to evaluate the flux change and ecosystem service for a given influx condition. Individual landscapes are all peculiar, but "categorized landscapes" are proposed in this study. Categorization is principally performed by classification of fluvial morphology and land use, and it is assumed that the mechanism of the ecosystem is "similar" in the same category. In Fig. 6, a fundamental framework of TB2 is shown, where the model is composed of (1) habitat suitability model, (2) population dynamics model and (3) model to evaluate ecosystem function against biomass for species focused in each categorized landscape.

Furthermore, we are preparing TB3 (Tool Box 3) to standardize and to integrate the ecosystem services accumulated in various landscapes in the river basins and the bay for total assessment. Figure 7 shows the flow chart to combine TB1-TB3. And, several institutes have responsibilities for subthemes as shown in Fig. 8.

\section{Evolution of restoration scenario in bay area}

Previous bay restoration program was based on water quality improvement program mainly due to layout of sewage system and disposal regulation for point sources in land area (river basins) and such strategies proved somewhat effective. With the beginning of the $21^{\text {st }}$ century, combining the concept of sustainability with ecosystem management, eco-compatible management of river basin for bay restoration has been focused on and introduced to the Tokyo-bay project (NILIM, 2005), where the eco-compatible 
management in river basins (land area) is effective in bay restoration from the view point of bay water quality. Eco-compatible river basin management is surely expected to suppress the load of non-point (distributed) sources. In addition, not only water quality but also the sound ecosystem and fishery productivity have been taken into account as the bay restoration target (NILIM, 2005). It is an advancement that the target of restoration has shifted from the water quality (output) to the ecosystem and/or fishery as human activity (outcome) in bay area. However, the efforts of the land and the effect in bay environment are focused, and thus citizens living in river basins (land area) are not always interested in participating in this program.

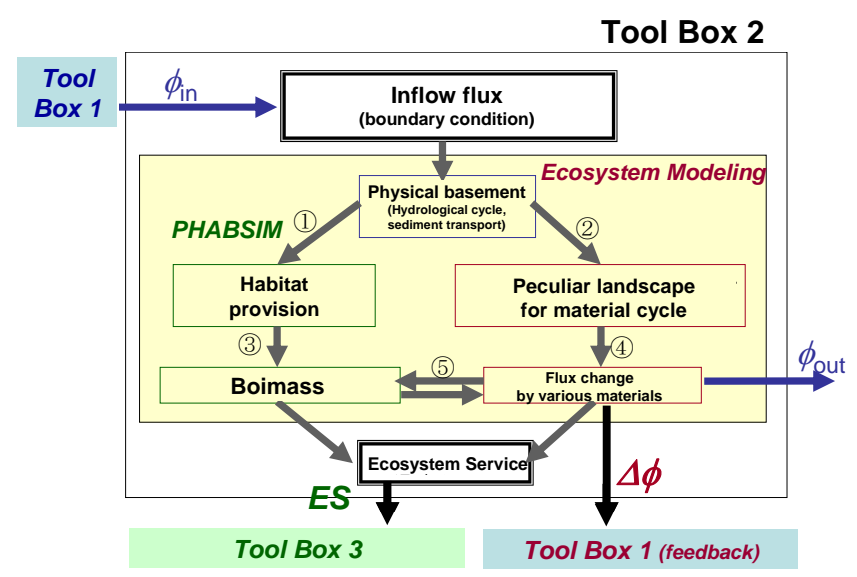

Figure 6. Framework of TB2 (Ecosystem modeling).

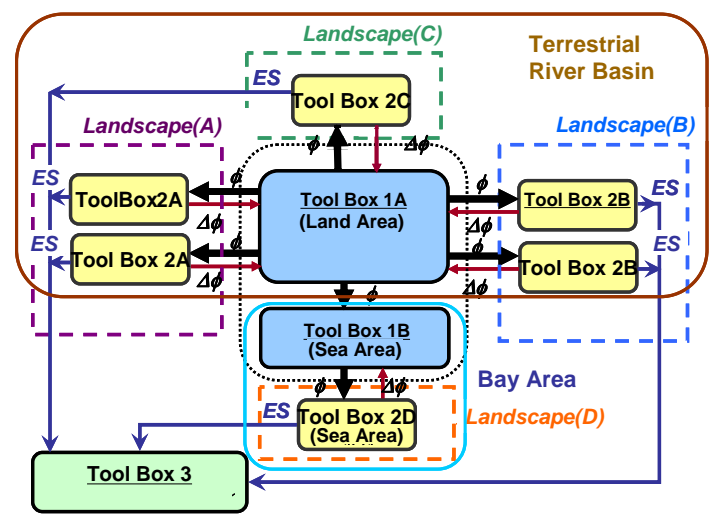

Figure 7. Flowchart to combine TB1, TB2 and TB3 for river basin assessment.

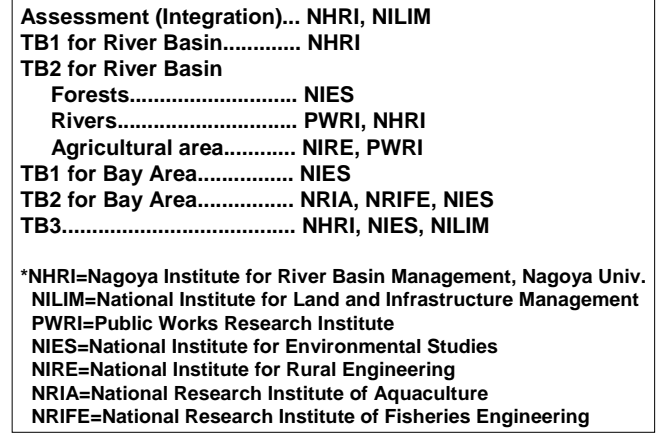

Figure 8. Subtopics and responsible institutes in research project.

In our project of restoration of which the target field is the river basin complex with Ise bay, we add to the restoration target river basins as well as bay area, where we add the target in river basins (land area). Not only ecosystem and fishery in bay area but also various ecosystem services contributing to human society must be optimized through eco-compatible management of river basin complex. Various landscapes (local 


\section{XI $I^{\text {èes }}$ Journées Nationales Génie Côtier - Génie Civil \\ Les Sables d'Olonne, 22-25 juin 2010}

ecosystems) bring ecosystem services by being passed by the flux network of water and various materials which are influenced by various landscapes reversely. We are preparing a methodology on how to describe this system and how to standardize and integrate various types of ecosystem services accumulated in various landscapes. Figure 9 demonstrates how the target and restoration menus have been changed as explained in this chapter.
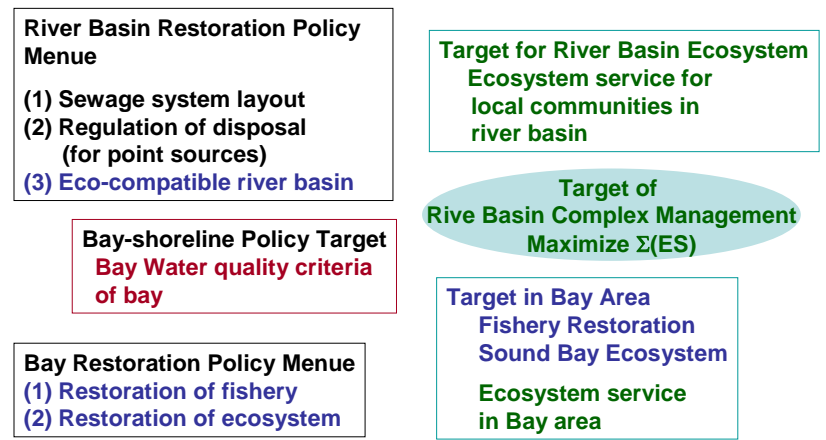

Figure 9. Evolution of strategy of bay restoration program.

\section{Models prepared in a bay area}

In this chapter is introduced the outline of TB1 and TB2 in a bay area (see Fig. 10).

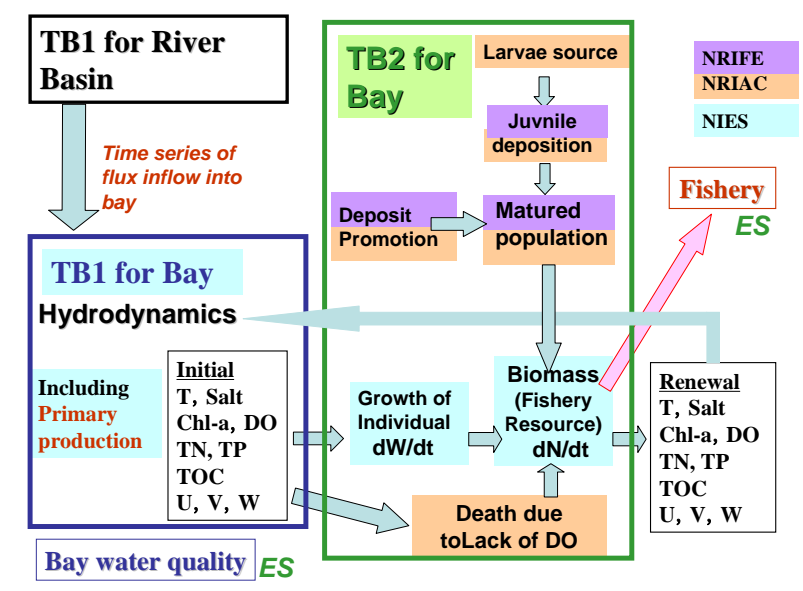

Figure 10. Framework of model with TB1 and TB2 in bay area.

As for TB1, the 3-D hydrodynamic model is the base, and not only physical parameters but also ecological indices are taken into account where inorganic and organic matters (dissolved and particulate) and phytoplankton are included. Numerical calculation is executed in the scheme with horizontal mesh of $2 \mathrm{~km}$ and with vertical mesh of $10 \mathrm{~m}$. According to tide, wind, air temperature, the discharge of major rivers with various materials and the boundary condition with the ocean, the time-space distribution of 
velocity vector, temperature, dissolved oxygen, chlorophyll-a, several nutrient indices are calculated. Figure 11 shows an example of calculated bay hydrodynamics (HIGASHI et al., 2009).
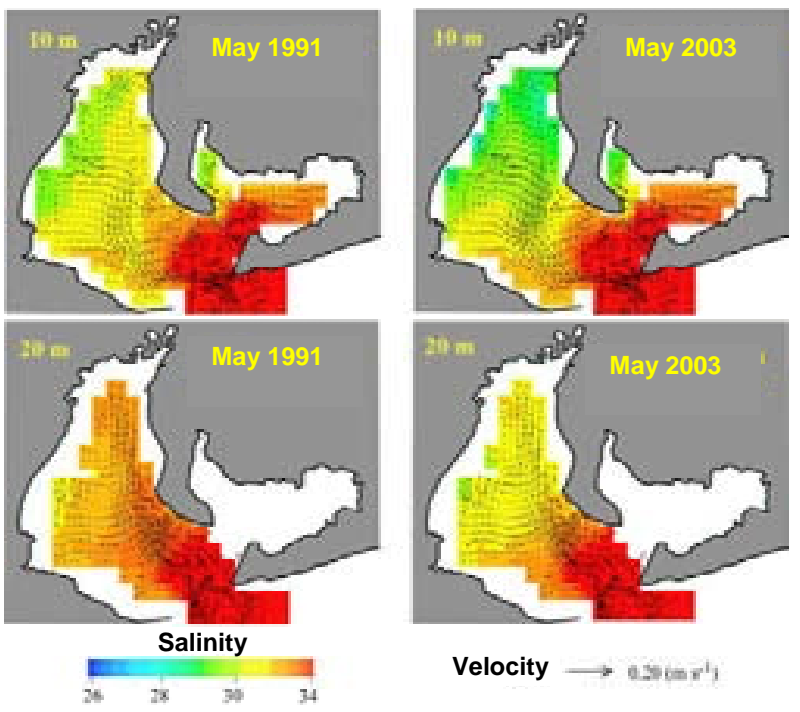

Figure 11. Example of numerical calculation of bay hydrodynamics.

On the other hand, life cycle of a typical species of bivalvia, short-neck clam (Manila clam), Ruditapes philippinarum, symbolic species for fishery in this area, is here focused on. Its habitat is a tidal flat as a categorized landscape. Tidal flat landscapes are located along shore of the Ise bay as shown in Fig. 12. The clams spawn, and their larvae drift, by hydrodynamics, to grow. Then, juveniles deposit on tidal flats. After stable staying of juveniles on a tidal flat, they grow by intaking particulate organic matters. Then, they mature, spawn and become fish resources. Based on such history of life, tidal flats distributed inside a bay contribute to a metapopulation of Ruditapes philippinarum. Hence, it is necessary to describe the drifting behavior of larvae (from where to where) subjected to the hydrodynamics, the stability for the landing of juveniles which are subjected to flow intensity and stability of substratum, and the growing process to be matured. They are parts of TB2 for tidal flat landscape with clam ecosystem. The increasing of biomass is identified with accumulation of nutrients by clam. It implies the clam fishery takes in role of water purification. NRIAC is preparing a model to describe life history (SAITO et al., 2007) and has developed a model to demonstrate the exchange in several tidal flat landscapes as metapopulation through the drifting process of lavae (HASEGAWA et al. submitted) subjected to bay hydrodynamics (TB1). Figure 13 shows examples of tracing simulation, and the drift has a tendency to migrate from north to south. In the meantime, NRIFE prepared the stability criteria in relation with the size of substratum and the flow intensity with sea bed morphology on tidal flats between stage from laeva to maturity (KUWAHARA, 
2008). Such a result may suggest restoration technique to improve fishery (HASEGAWA et al. 2009). After depositing on tidal flat successfully, it grows, depending on the feeding condition (mainly on Chlorophyll-a), but it is often damaged by storm disturbance and serious deficit of dissolved oxygen. NIES has prepared a model to describe the growth model of clam individuals and simultaneously accumulation of filtered particulate organic matter based on the study by HIWATARI $e t$ al. (2002).
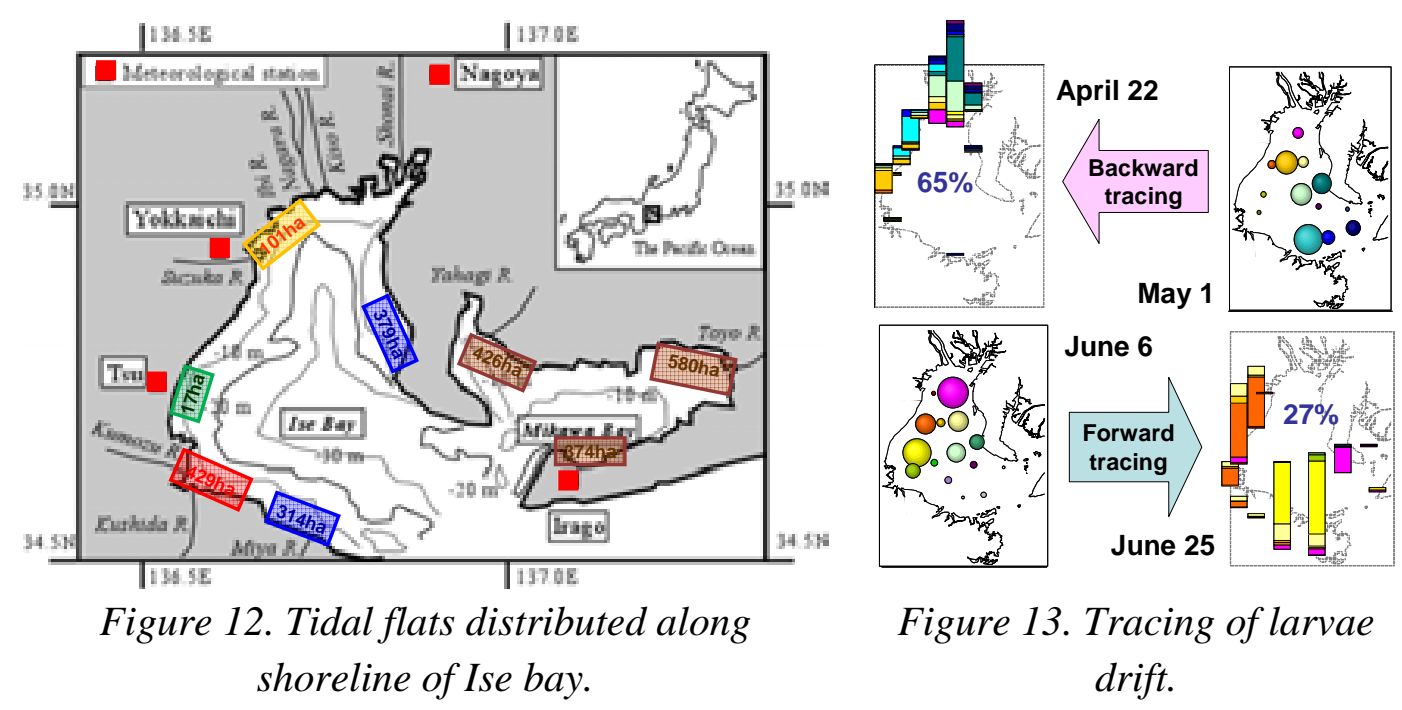

\section{Conclusion}

In this paper, the outline of our research project is to support Ise bay restoration program from the view point of eco-compatible management of river basin complex including the bay area. It is demonstrated how the strategy of bay restoration has evolved from focusing on the bay water quality to focusing on the integrated river basin management. The concept of river basin complex as distributed landscapes connected by flux networks of water and various materials has been explained. Eco-compatible management and ecosystem service is run by three tools boxes. Finally the outline of modeling in bay area has been introduced.

\section{References}

HASEGAWA N., HIGANO J., FUJIOKA Y., ISHII Y., MIZUNO T., MARUYAMA T., HODOKAWA K., SAKAMI T., SAITO R., KUWAHARA H. (2009). Relationship between the juvenile Manila clam Ruditapes philippinarum and the Nori-culture nets on tidal flats, Proc. Korea-Japan Sym. Tidal Flat.

HASEGAWA N., HIGANO J., FUJIOKA Y., ISHIHI Y., ICHIKAWA T., MIZUNO T., FUJITA K., HODOKAWA K. (Submitted). Meta-population structure of Manila clam Ruditapes philippinarum in Ise Bay, considering in its larval distributions. 
HIGASHI H., KOSHIKAWA H., KOHATA K., MURAKAMI S., MIZUOCHI M. (2009). A Numerical Study on Relationship between Water Quality and Wind Pattern Change in Ise Bay, Ann. Jour. Hydraul. Eng., JSCE, Vol. 53 (in Japanese, CD-ROM). HIWATARI T., KOHATA K., IIJIMA A. (2002). Nitrogen budget of the bivalve Mactra veneriformis, and its significance in benthic-pelagic systems in the Sanbanse area of Tokyo Bay, Estuarine, Coastal and Shelf Science. Vol. 55, No. 2, pp 299-308. doi:10.1006/ecss.2001.0905

KUWAHARA H. (2008). Effect of substratum characteristics on stability of depositing juvnile clams under uniform flow condition, Proc. Ann. Meeting, Jap. Soc. Fisheries Eng., pp 101-104 (in Japanese).

NILIM (2005). Watershed/ urban regeneration in accord with nature, Project Research Report, National Institute for land and infrastructure management, No. 2 (in Japanese)

SAITO H., TAKAHASHI H., MATSUDA A., ISHIHI Y., SAKAMI T., HIGANO J., KUWAHARA H. (2007). Considerations on the Fine-scale Topography in Sand Flats, Habitat Heterogeneity, and Refugia for Clams, Proc. 36th U.S.-Japan Aquaculture Panel Sym., pp 32-40.

TSUJIMOTO T., TODA Y., OBANA M. (2008). Assessment framework of ecocompatible river basin management around a bay, Advancement of Hydro-Science \& Eng., ICHE-Nagoya, Vol. 8 (CD-ROM).

TSUJIMOTO T., TODA Y., TAKAOKA H., OBANA M. (2010). Flux network modeling of water and materials in river basin complex for assessment in ecocompatible management, Advancement of Hydro-Science \& Eng., ICHE-Chennai, Vol. 9 (CD-ROM). 